\title{
MODELING OF BoSNIA-HERZEgovinA GROWTH Population
}

\author{
Musemic, R.; KorajceVic, S.; OMerovic, M. \& Bilac, B.
}

Abstract: The main topic of this work is modeling of the population growth in Bosnia and Herzegovina until 2050, by using logistic model with logistic equations and the official data from very last reliable sources in order to suplly the responsible authorities with relevant anticipated results for long-term development planning. Knowing concrete data from structural diagram we caught sight of which feedback will have strong impact on survival population. We found elements regulating the growth population and holding balance of the system. Almost thirty years Bosnia and Herzegovina falls into the group of low birthrate countries and just now is going to the depopulate phase of the natural trend. A lot of negative migration trends exerted on the decreasing birthrate and fertility. The results show the reliable parameters for trends of population growth.

Keywords: birth-rate, mortality (death) rate, mathematical modeling, demography
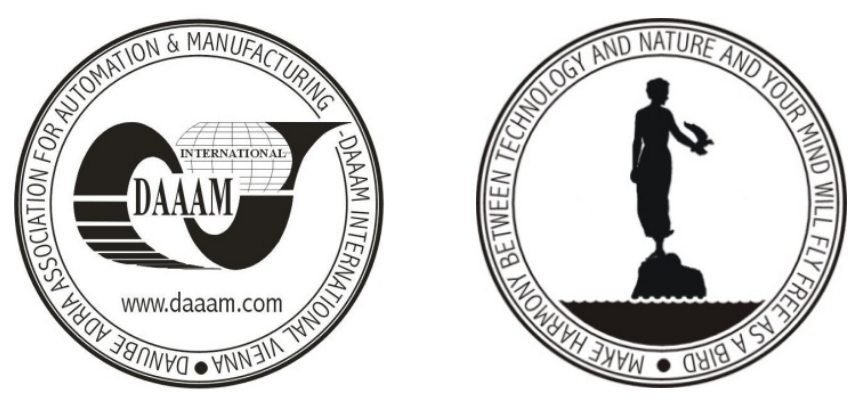

Authors' data: Prof. Dr. Musemic, R[ajfa]*; Dipl.-Ing. Korajcevic, S[evala]**; Dipl. Mat. Omerovic, M[idhat]***; Dipl.-Ing. Bilac, B[ernard]****, *University of Sarajevo, Faculty of Mechanical Engineering, Vilsonovo šetalište 9, 71000 Sarajevo, B\&H, **Agency for Statistics of Bosnia and Herzegovina, Sarajevo, ***High School 72220 Zavidovići, B\&H, ****Public Enterprise for Spatial Planning \&Town Settlement,72000 Zenica,B\&H, musemic@mef.unsa.ba, korajcevics@bhas.ba, midhat.omerovic@bih.net.ba, bibernard04@yahoo.com

This Publication has to be referred as: Musemic, R[ajfa]; Korajcevic, S[evala]; Omerovic, M[idhat] \& Bilac, B[ernard] (2009). Modeling of Bosnia-Herzegovina Growth Population, Chapter 65 in DAAAM International Scientific Book 2009, pp. 675-684, B. Katalinic (Ed.), Published by DAAAM International, ISBN 978-3901509-69-8, ISSN 1726-9687, Vienna, Austria

DOI:10.2507/daaam.scibook.2009.65 